\title{
業務用レンジから発生する上昇気流の性状把握およびモデル化 MEASUREMENT AND MODELING OF PLUME ABOVE COMMERCIAL COOKING STOVES
}

\author{
百瀬 敏 成*, 山中俊夫**, 甲谷寿 史***, 山本晃裕**** \\ Toshinari MOMOSE, Toshio YAMANAKA, Hisashi KOTANI \\ and Akihiro YAMAMOTO
}

\begin{abstract}
The purpose of this report is to make a plume model above commercial use cooking stove to simulate environment of commercial kitchen by CFD. We measured the temperature, air velocity, turbulence energy, concentration of tracer gas of plume above gas and induction heating commertial cooking stoves at $0.5 \mathrm{~m}$ to $1.5 \mathrm{~m}$ high. In results, it is made clear that the shape of distribution in each section can be expresssed Gaussian profiles, but it is difficult to predict value of commercial use cooking stove from value of domestic one.
\end{abstract}

Keywords : Commercial Kitchen, Cooking Stove, Plume, Measurement, Modeling

業務用㕌房, レンジ, 上昇気流, 測定, モデル化

1.はじめに

業務用的房では、発熱量が大きい上に調理時間が長時間となる ため、調理者にとって過酷な労働環境となる場合が多い。これを 改善するため様々な研究が行われており、近年は計算流体力学 (以下 CFD）による検討が多数行われている(12)。

CFDによる厨房環境の研究では、発熱源部分の境界条件として 発熱量を与える場合が多い。しかし厨房内の環境をより正確に再 現するためには、実験值に基づく上昇気流モデルを作成し、境界 条件の適切な設定方法の検証に用いることが有効と考えられる。

調理器具から発生する上昇気流の測定例としては、于ら ${ }^{3}$ が家庭 用のレンジを用いて発熱量 $0.85 \sim 2.5 \mathrm{~kW}$ 、加熱面からの高さ 0.8

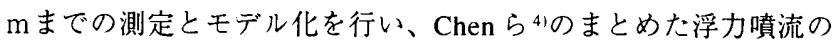
乱流プルーム域の式と比較して、最大值および特性長の高さ方向 変化が適合しないことを示している。また鎌田5)、千葉らの゙はガス レンジ $4.9 \mathrm{~kW}$ 、電気レンジ（シーズヒーターおよび八ロゲンヒー ター）について高さ $0.8 \mathrm{~m}$ までの風速分布を測定している。

業務用レンジについては寺沢ら》、坂口らが、レンジ上方から 給気口付のフード下面付近までの風速・温度分布を測定しており 発熱量 $7 \mathrm{~kW}$ において、風速分布を加熱面から高さ $0.25 \sim 0.85 \mathrm{~m}$ の 範囲で測定している。また近藤ら竞は、並行して行ったCFDによ る結果を実測値と比較して熱上昇気流の幅が小さく高温になる事 を示し、高温空気の膨張や水蒸気発生を考慮していないモデルに よる計算では上昇気流の混合、拡散を過小評価している可能性が
あることを報告している。

これら既往の測定例では、器具の発熱量は業務用レンジとして

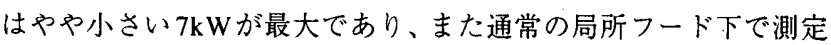
しているため、測定領域もレンジ上面から高さ $0.8 \mathrm{~m}$ までに限定さ れている。また乱流統計量については測定例がない。

CFDによるレンジ上方の上昇気流の再現精度を把握するには、 できるだけ間隔を広げた複数断面について上昇気流を測定し、 $\mathrm{CFD}$ の境界条件として低い位置の測定値を用い、より高い位置で のCFDによる結果を測定結果と比較検討することが望ましい。

そこで本研究では、一般的に業務用欴房で広く用いられている 発熱量の業務用ガスレンジ (以下ガス) と電磁調理器 (以下電磁) について、レンジからの高さ $0.5 \mathrm{~m} 、 1.0 \mathrm{~m} 、 1.5 \mathrm{~m}$ の 3 つ断面につ いて、温度、風速、トレーサーガス濃度の分布を測定し、実験値 に基づいたモデルを作成した。さらに高さ $0.5 \mathrm{~m}$ の断面について は、CFDでの境界条件として用いるために風速と乱流統計量の関 係についても測定した。高さ $0.5 \mathrm{~m}$ の測定結果を境界条件として利 用し、高さ $1.0 、 1.5 \mathrm{~m}$ での風速・温度の測定結果と比較することで CFDによる結果の検証を可能としている。

\section{2 . 実験方法}

調理器具として、表 1 に示す業務用に通常用いられるガス及 び電磁レンジを用いた。両者は発熱量は異なるが、表 2 るよ
大阪大学大学院工学研究科建築工学専攻 博士後期課程 $\cdot$ 修士 (工学)

** 大阪大学大学院工学研究科建築工学専攻 助教授・博士 (工学)

* * 大阪大学大学院工学研究科建築工学専攻 助手・博士 (工学)

**** 大阪大学大学院工学研究科建築工学専攻 大学院生
Graduate Student, Dept. of Architectural Eng., Graduate School of Eng., Osaka University, M. Eng.

Assoc. Prof., Dept. of Architectural Eng., Graduate School of Eng., Osaka University, Dr. Eng.

Research Assoc., Dept. of Architectural Eng., Graduate School of Eng., Osaka University, Dr. Eng.

Graduate Student, Dept. of Architectural Eng., Graduate School of Eng., Osaka 
うにほほ同等の沸騰能力をもつ。実験は図1〜3に示す 実験室で行った。実験室天井部には上昇気流の滞留を防ぐため の排気ファン・天井ファンを設置した。排気量はガスでは $1350 \mathrm{~m}^{3} /$ h、電磁は給気の影響を受けやすいので、給気風速を可能な限り小 さくするため $200 \sim 300 \mathrm{~m}^{3} / \mathrm{h}$ とした。給気は部屋の側壁面 3 万向全 面から行ったが、メッシュで覆うことで外乱の影響を抑制し、測定 毎に煙発生器(ロスコ社製 スモークマシン)を用いた可視化により加 熱前および加熱中のレンジ周囲の風速が $0.1 \mathrm{~m} / \mathrm{s}$ 以下であることを確 認した。発熱面から天井までの距離を確保するため、各レ ンジの発熱面高さは床上 $0.31 \mathrm{~m} に$ 設定した（図2参照）。 実験は鍋で水を定常沸騰させ、温度、風速、燃焼廃ガス、 調理污染物を対象として行った。測定点は、図4 に示すようにレン ジ上面から距離 $0.5 \mathrm{~m}, 1.0 \mathrm{~m}, 1.5 \mathrm{~m}$ の 3 段階の高さに、鍋を中心と する十字方向の各軸上に $5 \mathrm{~cm}$ 間隔で設定した（表3）。なお、濃 度については高さ $1.5 \mathrm{~m}$ での測定を省略し、乱流統計量は CFD の境

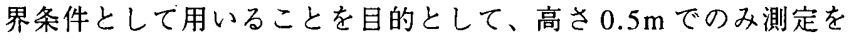
行った。

測定機器について表3に示す。温度は各高さ毎に同時に測定を行 い、風速、乱流統計量、濃度については1点ずつ測定を行った。温 度はアルミ箔の放射避けを付けたT型熱電対を鍋上方に十字状に設 置して測定した。平均風速の測定には中高温用の定温度型熱式風速 計（KANOMAX 製6162型 アネモマスター0〜200年用）を用いた。 風速計は図 5 のように上昇気流の下流側から接近させるようにし た。また熱式風速計には指向性があるため、事前に煙発生器を用い た可視化により主流方向が上向きであることを確認し、図5のよう に上向き方向を中心に測定した。さらにガスでは超音波風速計でも 主流方向を確認している淮1。定温度型熱式風速計への温度の影響に ついては、温度の影響を受けない測定法である相関利用法100.11)注2? 比較して誤差が $10 \%$ 程度であることを確認した注3。一方、乱流統

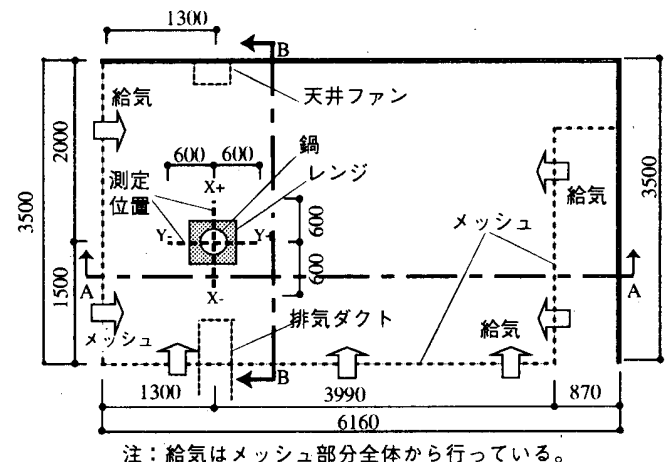

図 1 実験室上面図 単位 $[\mathrm{mm}]$

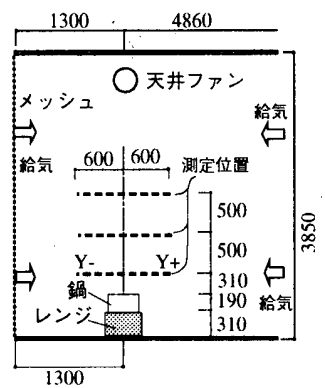

図 2 実験室断面図(A-A 断面) 単位 $[\mathrm{mm}]$

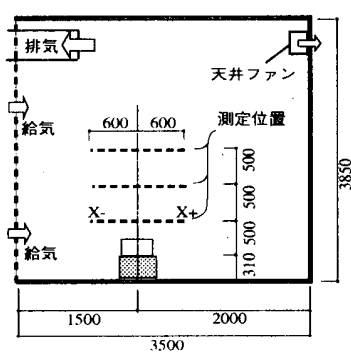

図 3 実験室断面図（B-B断面） 単位 $[\mathrm{mm}]$
計量を求めるための風速測定には、定温度式熱線風速計（I 型プ ローブ）を用いた。I型プローブは指向性があるため、上昇気流の 主流方向が上向きであることと乱流の等方性を仮定して上向きに 図 5 のように配置した。熱線風速計では風速変動だけでなく温度 変動の影響も受ける。温度補償に用いた直径 $0.12 \mathrm{~mm}$ の熱電対で は温度変動に対する応答性が十分とは言えず、温度変動を風速変 動として評価する可能性があり、乱流エネルギーの平方根はガス では最大風速の $15 \%$ 、電磁では $7 \%$ 程度の影響があることに注意 を払う必要がある注4)。

ガスの燃焼廃ガスの濃度分布については燃焼により発生する $\mathrm{CO}_{2}$ を測定し、調理污染物については鍋内に下向きにトレーサー ガスとして $\mathrm{SF}_{6}$ を放出し、これを各測定点で連続サンプリングし て測定した。

表 1 レンジ仕様

\begin{tabular}{|c|c|c|c|c|c|}
\hline 熱源 & ガス & 電磁 & \begin{tabular}{|l} 
熱源 \\
\end{tabular} & ガス & 電磁 \\
\hline 定格出力 [KW] & 14.5 & 5.0 & 15分間沸騰量 $[\mathrm{kg}]$ & 1.71 & 1.49 \\
\hline 器具形状 [m] & \multicolumn{2}{|c|}{ 幅 $0.45 \times$ 奥行 $0.60 \times$ 高さ 0.80} & & & \\
\hline 加熱容器 [m] & \multicolumn{2}{|c|}{ 直径 $0.37 \times$ 高さ 0.19 SUS製 } & & & \\
\hline
\end{tabular}

表 3 実験装置と実験条件

\begin{tabular}{|c|c|c|c|c|c|c|}
\hline $\begin{array}{l}\text { 計測 } \\
\text { 対象 }\end{array}$ & 測定機器 & $\begin{array}{l}\text { レンジ } \\
\text { 上面から } \\
\text { 高さ [m] } \\
\end{array}$ & \begin{tabular}{|c|} 
鍋中心から \\
測定範囲 \\
{$[\mathrm{m}]$}
\end{tabular} & $\begin{array}{l}\text { 間隔 } \\
\text { [m] }\end{array}$ & $\begin{array}{l}\text { 測定 } \\
\text { 回数 }\end{array}$ & 備考 \\
\hline 温度 & T型 熱電対 & \begin{tabular}{|l|}
0.5 \\
1.0 \\
1.5 \\
\end{tabular} & 0.6 & 0.05 & \begin{tabular}{|c|}
5 秒每 \\
60 回
\end{tabular} & $\begin{array}{l}\text { 同一宫さは } \\
X Y \text { 軸上全点 } \\
\text { を同時測定 } \\
\text { 各高さ } 2 \text { 回 }\end{array}$ \\
\hline 風速 & \begin{tabular}{|l|} 
定温度型 \\
熱式風速計 \\
KANOMAX製 \\
6162 型 \\
温度補償精度 \\
$0-200^{\circ} \mathrm{C}$ FS $15 \%$ \\
\end{tabular} & $\begin{array}{l}0.5 \\
1.0 \\
1.5\end{array}$ & 0.5 & 0.05 & $\begin{array}{l}1 \mathrm{~Hz} \\
60 \text { 回 }\end{array}$ & \begin{tabular}{|l}
1 点つうつ \\
順次測定 \\
$X, Y$ 軸方向 \\
各 2 回
\end{tabular} \\
\hline $\begin{array}{l}\text { 風速 } \\
\text { (乱流統計量) }\end{array}$ & \begin{tabular}{|l|} 
定温度型 \\
熱線風速計(I型) \\
KANOMAX製 \\
0251R-PI5 (ガス) \\
0251T5 (電磁)
\end{tabular} & 0.5 & 0.5 & 0.05 & $\begin{array}{l}250 \mathrm{~Hz} \\
20 \text { 秒間 }\end{array}$ & 同上 \\
\hline $\begin{array}{l}\mathrm{SF}_{6} \\
\text { 潧度 }\end{array}$ & \begin{tabular}{|l|} 
リアルタイム \\
ガスモニタ1311型 \\
Bruel\&Kjaer製
\end{tabular} & $\begin{array}{l}0.5 \\
1.0\end{array}$ & $\begin{array}{l}\text { ガス: } 0.5 \\
\text { 電磁: } 0.3\end{array}$ & 0.1 & $\begin{array}{l}1 \text { 秒每 } \\
120 \text { 回 }\end{array}$ & \begin{tabular}{|l|}
1 点づつ \\
順次測定 \\
$X, Y$ 軸方向 \\
各1回 \\
\end{tabular} \\
\hline \begin{tabular}{|l}
$\mathrm{CO}_{2}$ \\
滄度
\end{tabular} & \begin{tabular}{|l} 
赤外線式 \\
堀場製 VIA-510
\end{tabular} & $\begin{array}{l}0.5 \\
1.0 \\
\end{array}$ & ガス: 0.5 & 0.1 & \begin{tabular}{|l|} 
1秒每 \\
120回 \\
\end{tabular} & 同上 \\
\hline
\end{tabular}

測定間隔は、鍋中心から $0.4 \mathrm{~m}$ 以遠は $0.1 \mathrm{~m}$ 間隔

表 4 実験設備機器

\begin{tabular}{|c|c|c|}
\hline 設備機器 & 機器名称 & 備考 \\
\hline 排気ファン & $\begin{array}{l}\text { ナショナル } \\
\text { FY55DTH }\end{array}$ & $\begin{array}{l}\text { 定格1500W } \\
\text { 設定排気量 ガス } 1350 \mathrm{~m} 3 / \mathrm{h} \text { 電研 } 2 \sim 300 \mathrm{~m}^{3} / \mathrm{h}\end{array}$ \\
\hline 天井ファン & 三菱電機 防篧型 & 定格 300W (天井上部空気排出用) \\
\hline ガス流量調整器 & 低圧用圧力調整器 & 設定圧力 $19.6 \mathrm{~Pa}(200 \mathrm{mmAq})$ \\
\hline $\mathrm{SF}_{6}$ 流贵調整器 & マスフロー流量調整器 & 設定流量 $2.6 \mathrm{~L} / \mathrm{min}$ \\
\hline $\mathrm{SF}_{6}$ ガス発生器 & 鍋内環状ガス放出器 & $\begin{array}{l}\text { 直径0.225m、 } \\
\text { 下向きに直径0.01mの穴を10個 等間隔配置 }\end{array}$ \\
\hline & 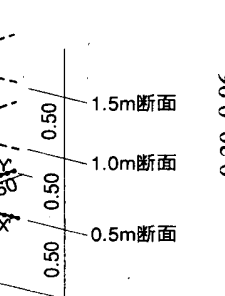 & ガイドレール \\
\hline
\end{tabular}

(a) 風速 (b)乱流統計量

図 4 測定点 単位 $[\mathrm{m}]$ 


\section{3. 実験結果}

\section{1 温度分布}

上昇気流の温度分布の測定結果を図6に示す。ガス、電磁ともに レンジ上面からの距離が大きくなると温度が低くなる。特に電磁で は、高さ $1.5 \mathrm{~m} て ゙ は$ 周囲との温度差が最大で $4{ }^{\circ} \mathrm{C}$ と非常に小さい。各 条件での温度分布はばらつきが少なく正規分布に近い分布を示して いるが、測定回によって温度が最高值になる位置が水平方向にずれ る結果も見られた。特にガスで $0.5 \mathrm{~m}$ の場合のみ $\mathrm{X} 、 \mathrm{Y}$ 軸の結果に 若干の差がみられるのは、燃焼廃ガスがごとく形状や鍋の取っ手の 影響を受けているためと考えられる。
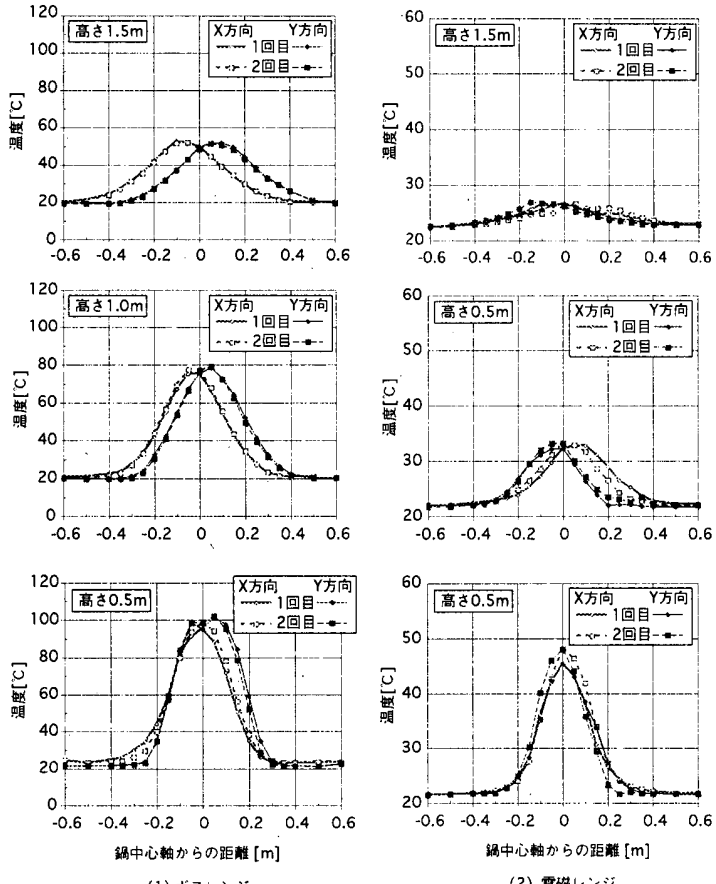

図 6 上昇気流の温度分布
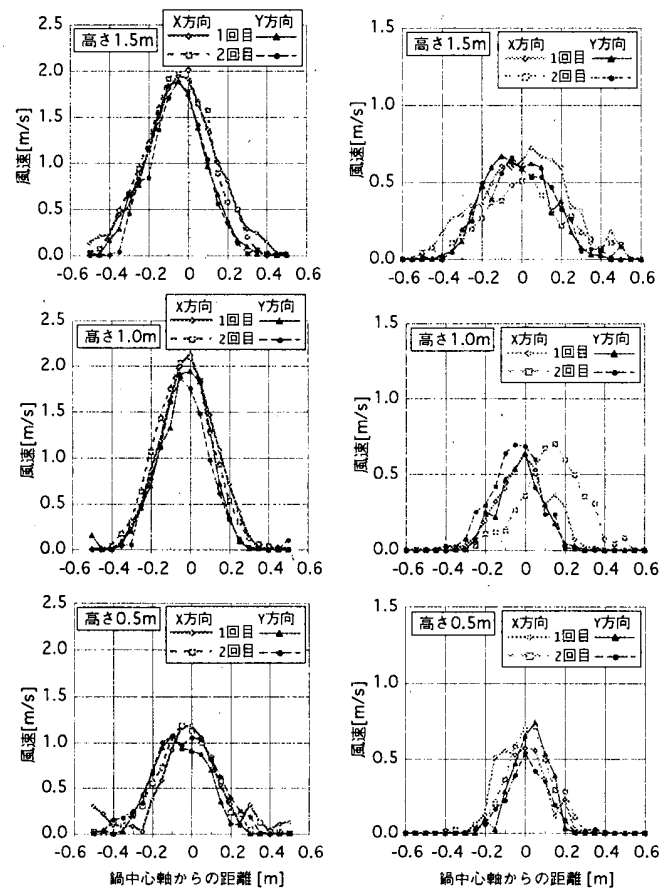

(1) ガスレンジ

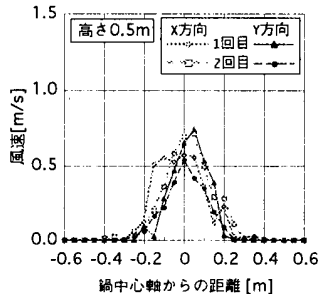

(2) 震磞レンジ

図 7 上昇気流の風速分布（中高温用定温度型熱式風速計による）

\section{2 風速分布}

中高温用の定温度型熱式風速計を用いて測定した上昇気流の風速 分布の測定結果を図7に示す。温度同様、ガスの方が電磁に比べて 大きく、最高風速はガスは電磁の約 2 倍である。また、レンジから

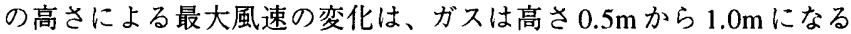

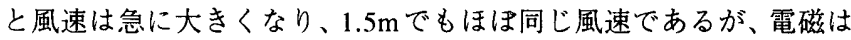
高さ $0.5 \mathrm{~m}$ から $1.5 \mathrm{~m}$ まで最大風速の変化は少なくほほ一定に近い。 中心軸から遠い位置での風速はレンジからの距離が遠いほど大きく なっている。温度の測定結果と比べると、測定值のばらつきが大き

\section{表 5 乱流統計量の計算方法}

乱流エネルギー* $: k\left[\mathrm{~m}^{2} / \mathrm{s}^{2}\right] \quad k=\frac{1}{2}\left(\frac{3}{2} \overline{u^{\prime 2}}\right) \quad \overline{u^{\prime 2}}$ : 風速測定值の分散 $\left[\mathrm{m}^{2} / \mathrm{s}^{2}\right]$

時間スケール $: T[\mathrm{~s}] \quad T=\int_{0}^{\infty} \rho(\tau) d \tau \quad \rho(\tau)$ : 風速測定值の分散 $\left[\mathrm{m}^{2} / \mathrm{s}^{2}\right]$

\begin{tabular}{l}
\hline 淂の長さスケール: $\ell[\mathrm{m} \mid \quad \ell=\bar{u} \times T \quad \bar{u}:$ 平均風速 $[\mathrm{m} / \mathrm{s}]$ \\
\hline *I型プローブを用いたので、2 方向成分を測定していると考え，
\end{tabular}

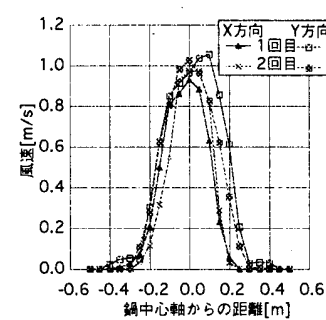

(1) ガス

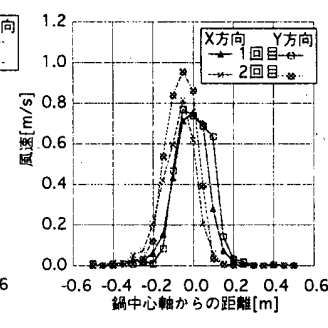

(2) 電磁

図 8 風速分布（高さ $0.5 \mathrm{~m}$ 熱線風速計による）

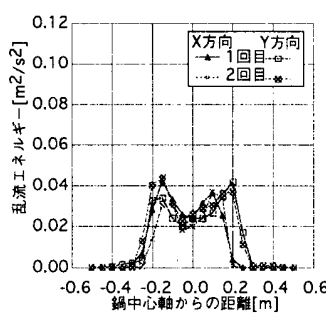

(1)ガス

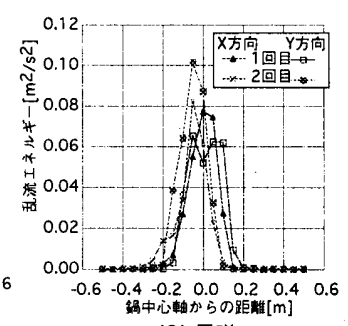

図 9 乱流エネルギー分布

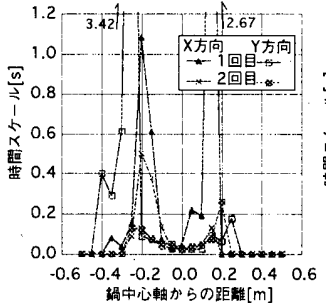

(1) ガス

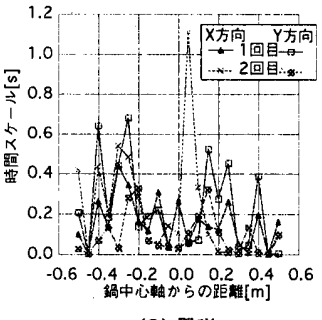

(2) 笔磁

図 10 時間スケール分布

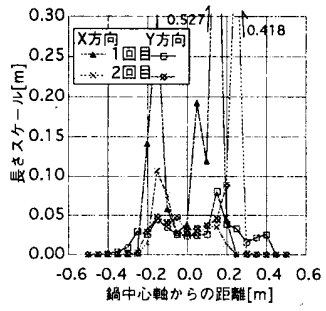

(1) ガス

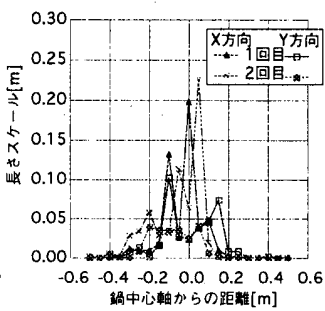

(2) 電磁

図 11 渦の長さスケール分布 
いが、これは実験ごとに給気のバランスが若干変化しているため と考えられ、原因としては実験室のケーブル貫通部や出入口等に わずかにある隙間が測定毎に若干異なること等が考えられる。同 一条件で温度分布を30分間測定して上昇気流の中心軸の変動幅を 確認した所、高さ $1.0 \mathrm{~m}$ で 5 分間平均值の変動幅は半径 $0.01 \mathrm{~m}$ 以下 であったことから各測定毎の定常性には問題ないと判断した。

\section{3 乱流統計量の分布}

I 型プローブによる熱線風速計を用いた風速の測定結果から、表 5 に示す計算方法にもとづいて上昇気流の乱流エネルギー $k$ と時間 スケール $T$ を測定した。時間スケール $T$ は渦が空間の 1 点を通り 過ぎる時間を表しており、これを用いて渦の長さスケールとを求め ることができる。

高さ $0.5 \mathrm{~m}$ での風速の測定結果を図 8 に示す。前節の中高温用定 温度型熱式風速計による測定結果と比較すると、最大風速はガス、 電磁とも同程度であることがわかる。次に、乱流エネルギーと中 心軸からの距離の関係を図 9 に示す。電磁は中心部で最大值をと るが、ガスは外側の鍋の端付近で最大となっている。これは2章で 述べた温度変動による影響があるためと考えられる。またガスは

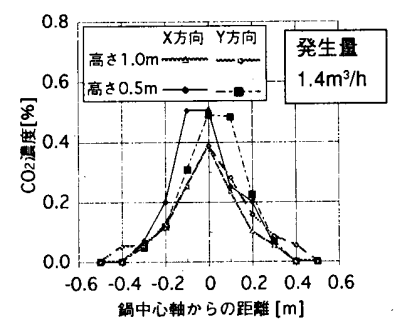

(a) ガス $\mathrm{CO}_{2}$

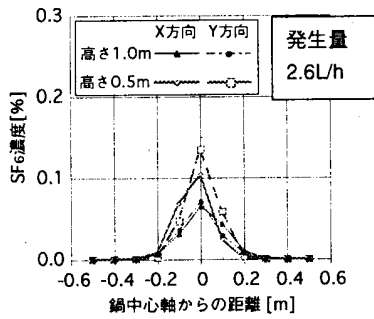

(b) ガス $S F_{6}$

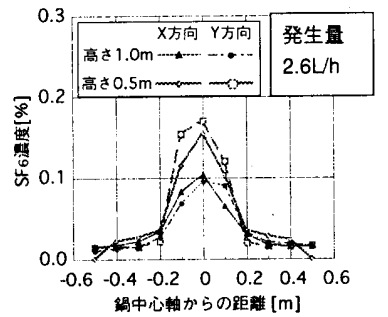

(c) 電磁 SF 図 12 上昇気流のトレーサー濃度分布

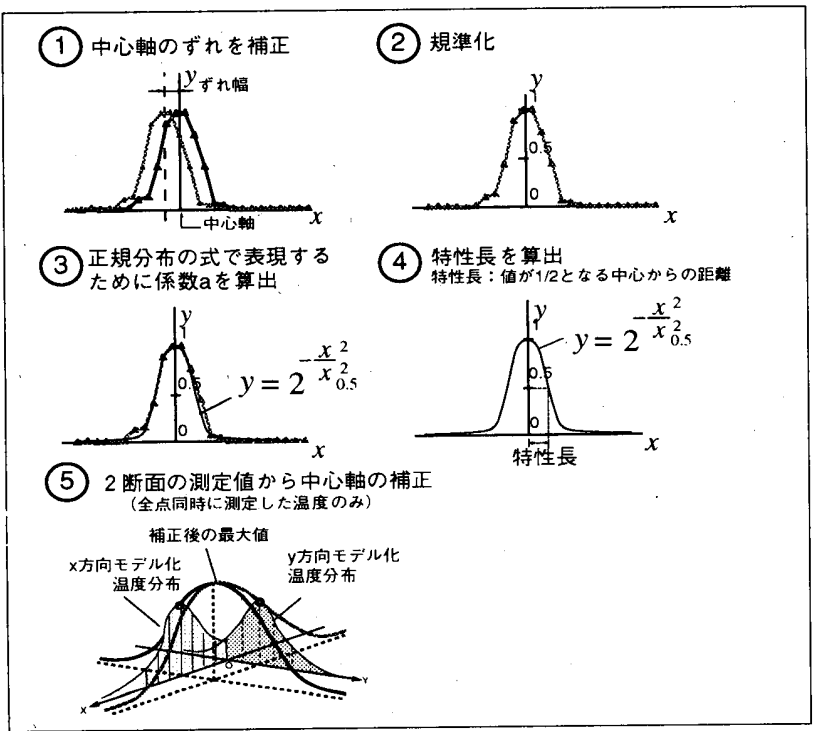

図 13 モデル化の方法
電磁に比べて值が小さい。時間スケールと中心軸からの距離との関 係を図 10 に示す。顕著な傾向は見られないが、概ねガス、電磁と もに時間スケールは鍋中心付近で小さく、鍋の端付近で大きくなる 傾向があることが分かる。

図 11 に長さスケールと中心軸からの距離との関係を示す。長さ スケールは速度と時間スケールの両方を用いて算出されるため、流 速の大きい中心部が大きい傾向はあるが、風速分布とは一致してい ないことがわかる。

時間スケールおよび渦の長さスケールの分布に顕著な傾向が見ら れないことから、CFDの境界条件として実験值の渦の長さスケール の分布をそのまま適用するには問題があることがわかる。

3.4 トレーサーガス濃度分布

トレーサーガス濃度分布の測定結果を図 12 に示す。 $\mathrm{CO}_{2}$ 濃度、 $\mathrm{SF}_{6}$ 濃度いずれにおいても、高さ $1.0 \mathrm{~m}$ の濃度の方が $0.5 \mathrm{~m}$ より濃度 が小さい事が分かる。またガスに比べ電磁は約 1.5 倍の濃度となっ ている。これは上昇気流の流量がガスよりも電磁の方が小さいため と考えられる。

\section{4. 上昇気流モデルの作成}

\section{1 モデル化の方法と結果}

測定結果を基にして温度、風速、濃度分布のモデル化 を試みた。 $\mathrm{x}$ 方向、y 方向各断面での各測定結果について、 図13のように距離の重み付け平均した値を用いて中心軸位置を補 正し、さらに 1 列の測定結果の最高值と最低值を用いて測定値を無

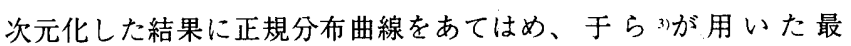
大値の半分となるまでの距離である特性長を式(1)に基

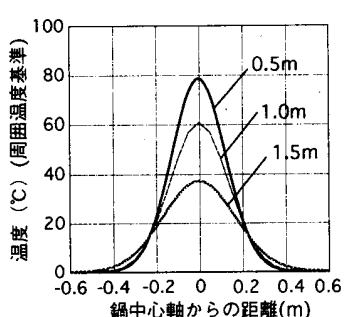

(1) 温度分布 (ガス)

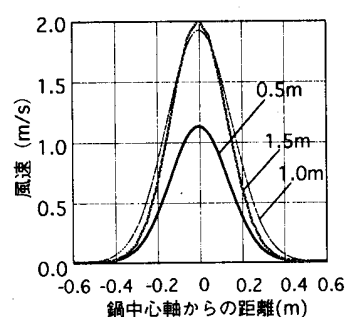

(3) 風速分布（ガス）

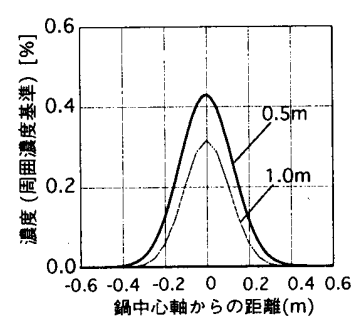

(5) $\mathrm{CO}_{2}$ 搌度分布（ガス）

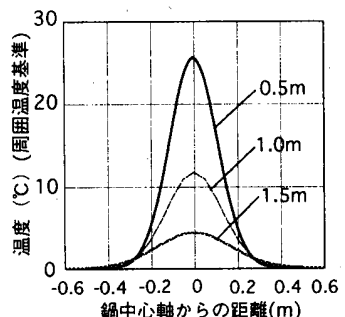

(2) 温度分布 (電磁)

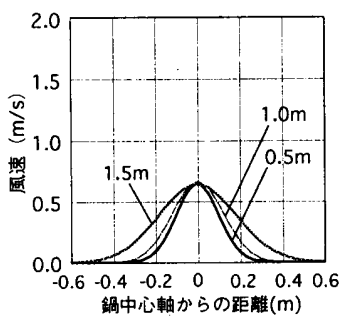

(4) 風速分布 (電磁)

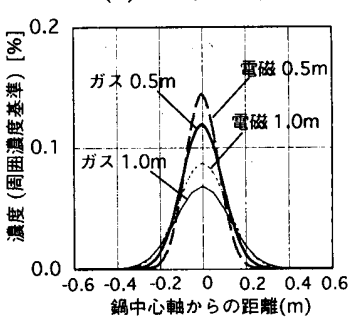

(6) SF6漕度分布 (ガス，電磁)
図 14 上昇気流のモデル化 
づいて算出した。

$$
\phi=\phi_{m} 2^{-\frac{x^{2}}{x_{0.5}^{2}}}
$$

$\phi \quad$ :温度、風速、濃度のいずれか

$\phi_{m}$ : 最大值

$x \quad$ :鍋中心からの距離

$x_{0.5} \quad$ : 特性長

$[\mathrm{m}]$

さらに温度については、同一水平面内の測定では同時性が確保さ

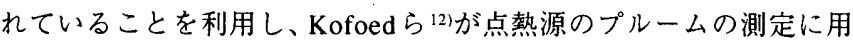
いた方法を参考に、中心軸のずれを求めた上で、2 次元の正規分布 曲面を用いて、測定した 2 軸上からずれた位置にある最大値を推定 した。この推定方法は実際の最高温度より低く見積もる傾向があっ たが、本試験での測定誤差は周囲温度基準で $10 \%$ 以内と見積もられ る注5)。

モデル化により得られた各測定対象の各高さでの水平面分

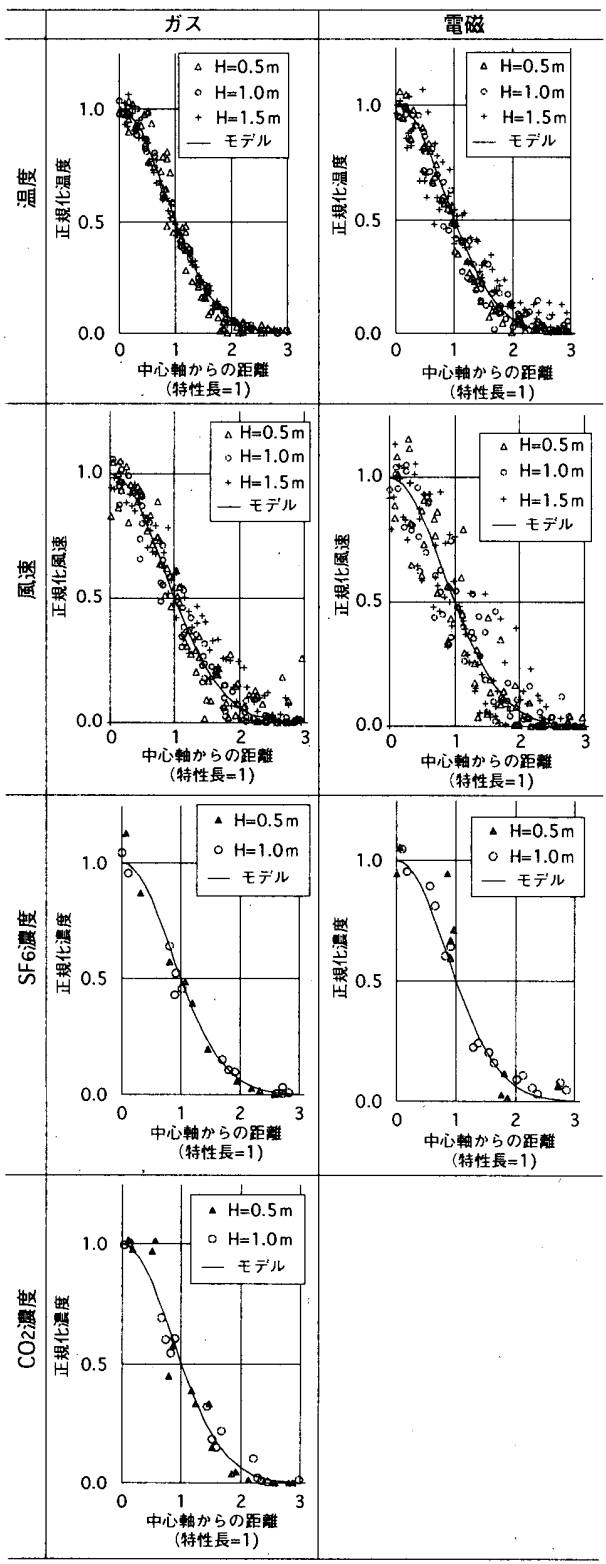

図 15 モデルと測定結果の比較
布を図 14 に示す。またモデル化の妥当性を確認するため、モデ ル化した值を基準にした測定結果の分布状況を図15に示す。測定 結果とモデルを比較すると、温度、濃度ではよく一致している。 風速の特に電磁ではややばらつきが大きいが、モデルはほほ平均 的な測定值を代表しているといえる。次にモデル化した結果をみ ると、温度は、ガス、電磁共レンジからの高さが大きく なるにつれて最大值の分布が急激に小さくなってい る。風速はレンジからの高さによりガスでは全体に大きく なるが、電磁は最大值は変化せず外側の風速だけが大きくなる。 $\mathrm{CO}_{2}$ 濃度、SF 濃度はレンジからの高さにほほ反比例し て濃度が小さくなっている。

次に、特性長とレンジからの高さとの関係を図 16 に示す。温 度の特性長はレンジからの高さが大きくなるほど大きくなり、風 速ではガスの特性長はレンジからの高さにかかわらずほほ一定で ある。一方、濃度については、 $\mathrm{SF}_{6}$ はレンジからの高さが大きく

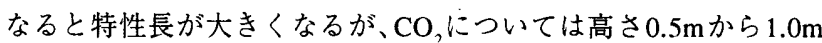
になると、特性長が小さくなり、 $\mathrm{SF}_{6}$ 㧍よび温度、風速の特性長 の值に近くなる結果となった。これは鍋の外側から上昇してきた 燃焼廃ガスが、縮流に伴い中央に集まってくるためと考えられる。 このためCFDの初期条件としてこれらのトレーサーガスを扱う場

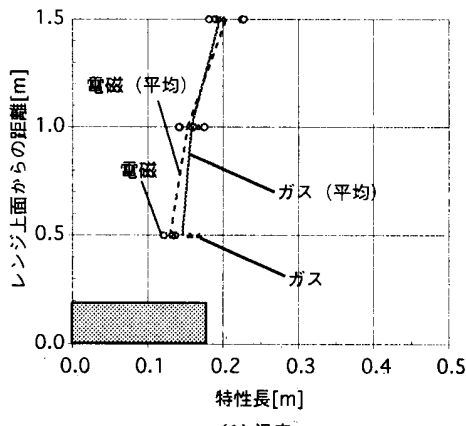

(1) 温度

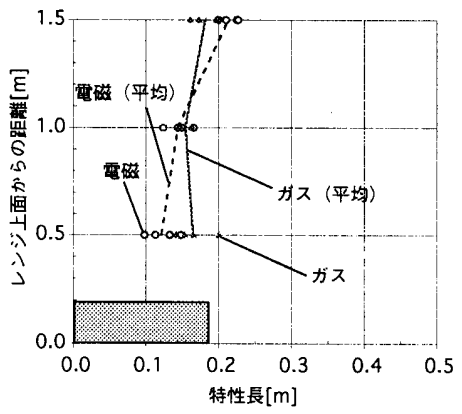

(2) 風速

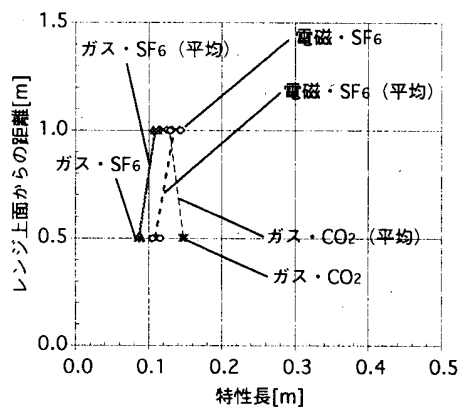

(3) $\mathrm{CO}_{2}, \mathrm{SF}_{6}$ 湿度

図16レンジ上面からの高さと特性長の関係 
合は、鍋内から発生する調理污染物と燃焼廃ガスは発生箇所を分 離した方がよい可能性がある。また図17はレンジからの高さと 最大值の関係を示している。これから、特にガスにお いてレンジからの高さが大きくなるにつれ温度の最大 值が急速に小さくなる傾向が分かる。また風速の最大值 はガス、電磁共、変化が小さいが、電磁の高さ $1.5 \mathrm{~m}$ の最大 值は $1.0 \mathrm{~m}$ の場合より低くなっている。また S F。濃度 は、各高さで電磁がガスの 1.5 倍の值となっている。

各特性長と最大值から、断面通過流量と断面通過顕熱を求めた。 最大風速からその $1 / \mathrm{e} の$ 風速の值までの通過流量は以下の式から求 められる。

$$
Q(z)=3600 \cdot 2 \int_{0}^{x}{ }_{1 / r u} U(z, x) \pi x d x
$$

$Q(z):$ 鍋上方高さ $\mathrm{z}[\mathrm{m}]$ の水平面を通過する上昇気流の 体積流量

$U$ : 上昇気流の上向き風速

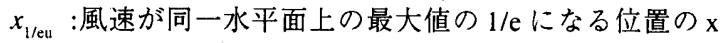

この式と風速についての分布の式(1)から積分は以下のように求め られる。

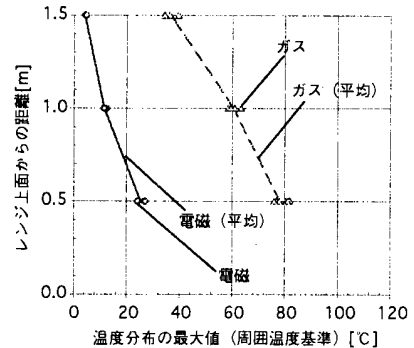

(1) 温度

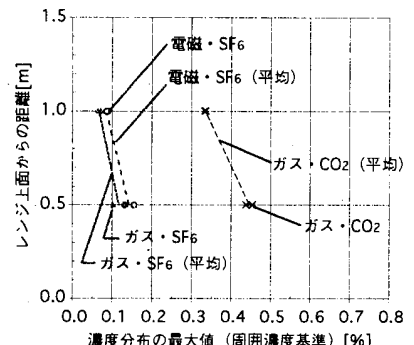

(3) 濃度

図17レンジ上面からの高さと最大值との関係

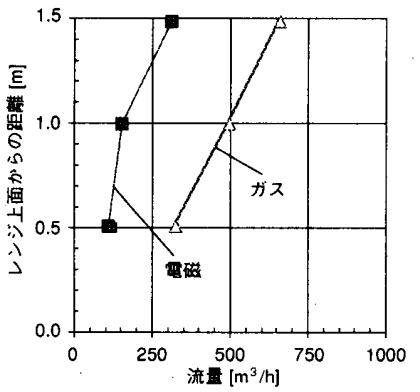

図 18 上昇気流の断面通過流量

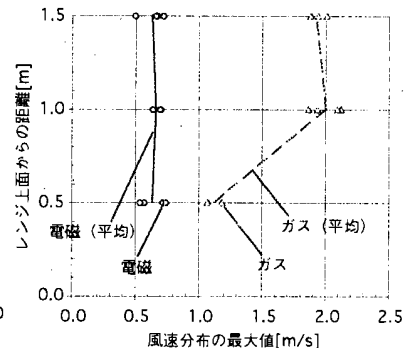

(2) 風速

$$
Q(z)=\frac{U_{m}(z) \pi \times 0.5 u(z)}{\log 2}\left(1-\frac{1}{e}\right) \cdot 3600
$$

$U_{m}(z)$ :高さ $z[\mathrm{~m}]$ の水平面上の風速の最大值

$[\mathrm{m} / \mathrm{s}]$

この式から求めた断面通過流量の計算結果を図 18 に示す。断面 通過流量はレンジからの高さが大きくなると、電磁、ガスともに漸 增する。

断面通過顕熱は数值的に積分して算出した。この結果を図 $19 に$ 示す。レンジからの高さが変化しても、断面通過熱量は電磁、ガス ともにあまり大きく変化していない。また電磁の通過顕熱が発熱量 に対し非常に小さい。これは発熱量の大半が潜熱となっているため と考えられる。

\section{2 乱流エネルギーと風速の関係のモデル化}

前章で測定した乱流エネルギーの平方根 $\sqrt{k}$ と平均風速 $U$ の相関関 係を図 20 に示す。これから電磁では鍋上方の上昇気流の平均風速 $U$ と乱流エネルギー $k$ の間に $U \propto \sqrt{k}$ の関係があることがわかる。ガ スでは比例せず上に凸な曲線となっているが、これは2章で述べた ように温度変動の影響による可能性があると考えられる。

\section{5. 既往の測定結果との比較}

既往の各種レンジにおける測定結果と今回の測定結果を比較した 結果を図21に示す。

電磁は器具の発熱量が大きいにも関わらず、過去の家庭用電気レ ンジ（シーズヒーター）と比べ温度は低く風速は同等である。これ は電磁がシーズヒーターよりも熱効率が大きいため発熱量に占める 潜熱量の割合が大きく顕熱量が小さいためと考えられる。ガスでは 家庭用よりも温度、風速共に大きい。これは今回測定に用いた業務 用レンジが家庭用レンジより発熱量が大きいためと考えられる。

次に浮力噴流における発熱量・発熱源直径と温度、風速との関俰 を用いて、既往の電気、ガスの測定結果を、今回のガスおよび電磁 レンジの試験条件への換算を行った。

浮力噴流モデルについては式(4),(5)から、発熱量、発生源直径と 温度、風速の関係が求められる。

$$
\begin{aligned}
& T_{m}(z)-T_{a}=B_{t}\left(T_{a}+273\right) \frac{1}{g D}\left(\frac{W_{o}}{\rho_{a} D}\right)^{2 / 3}\left(\frac{Z^{\prime}}{D}\right)^{-5 / 3} \\
& U_{m}(z)=B_{u}\left(\frac{W_{o}}{\rho_{a} D}\right)^{1 / 3}\left(\frac{Z^{\prime}}{D}\right)^{-1 / 3}
\end{aligned}
$$

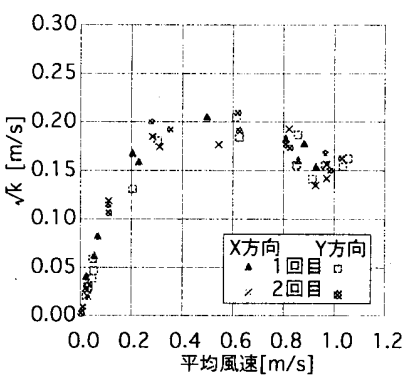

(1) ガス

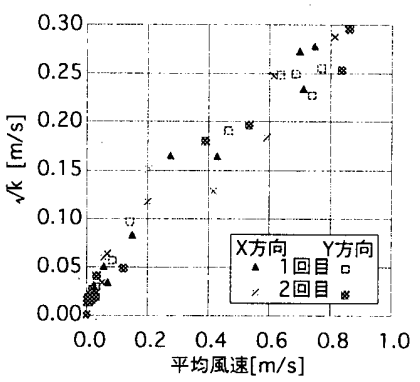

(2) 電磁 


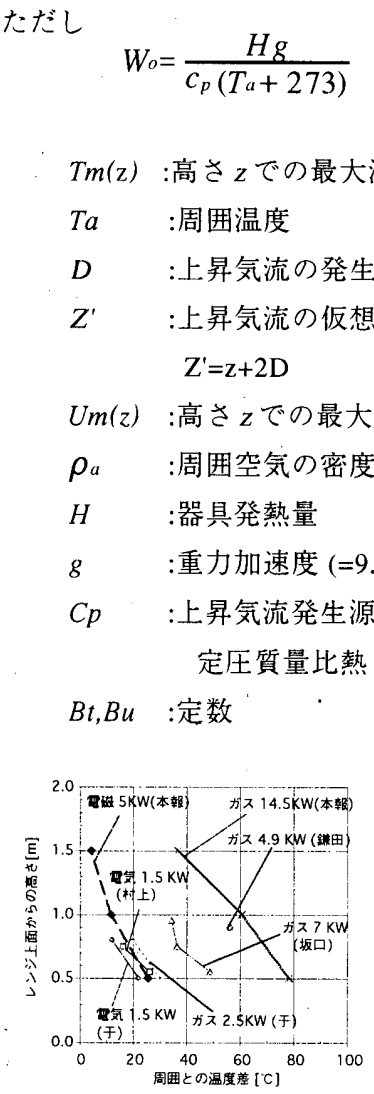

(1) 最高温度

周囲との温度差 $[\mathrm{C}$ 図 21 既往のレンジの上昇気流との比較（測定值）

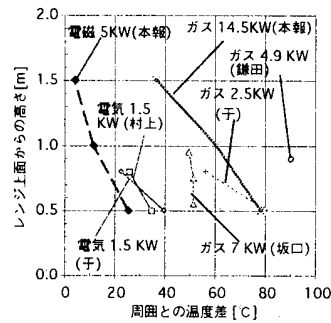

(1) 最高温度

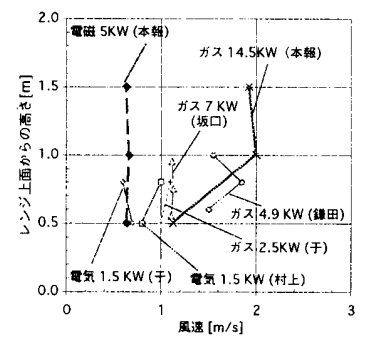

(2) 最高風速 $\left[{ }^{\circ} \mathrm{C}\right]$

$[\mathrm{m}]$

$[\mathrm{m} / \mathrm{s}]$

$\left[\mathrm{kg} / \mathrm{m}^{3}\right]$

[W]

$\left[\mathrm{m} / \mathrm{s}^{2}\right]$

$[\mathrm{J} / \mathrm{kgK}]$
(4)、(5)、(6) より、器具発熱量の異なる 2 つの器具の、発熱源 からの高さが同じ位置での、上昇気流の速度と温度は以下のよう に換算することができる。

$$
\begin{array}{cc}
\frac{U_{m a}}{U_{m b}}=\left(\frac{H_{a}}{H_{b}}\right)^{1 / 3}\left(\frac{z+2 D_{a}}{z+2 D_{b}}\right)^{-1 / 3} & \\
\frac{T_{a}-T_{m a}}{T_{a}-T_{m b}}=\left(\frac{H_{a}}{H_{b}}\right)^{2 / 3}\left(\frac{z+2 D_{a}}{z+2 D_{b}}\right)^{-5 / 3} & \\
H_{a}, H_{b} \quad: \text { 器具 } a, b \text { の発熱量 } & {[\mathrm{W}]} \\
D_{a}, D_{b} \quad: \text { 器具 } a, b \text { の鍋の直径 } & {[\mathrm{m}]} \\
U_{m a}, U_{m b}: \text { 器具 } a, b \text { 上䄯気流の最大風速 } & {[\mathrm{m} / \mathrm{s}]} \\
T_{m a}, T_{m b}: \text { :器具 } a, b \text { の昇気流の最大温度 } & {\left[{ }^{\circ} \mathrm{C}\right]}
\end{array}
$$

これから、既往のレンジの測定結果を今回の業務用レンジの值に 換算すると図22のようになる。ガスの場合、既往の結果からの換 算值は本報の測定值よりも温度は小さく、風速では逆に大きいこ とがわかる。電磁の場合、既往のシーズヒーターの結果を用いた 換算值は、特に風速では本報の電磁の測定値に比べて非常に大き い。これは電磁がシーズヒーターよりも熱効率が高いため、発熱 量当たりの顕熱発生量が小さいためと考えられる。

次に特性長について既往の測定結果と比較した結果を図 $21 に$ 示 す。今回の業務用レンジの温度特性長はガス・電磁ともに、既往 の家庭用ガスレンジ $(2.5 \sim 5 \mathrm{~kW})$ の約 2 倍であるが、既往の業務用 レンジ $(7 \mathrm{~kW})$ の結果とはほぼ同等である。風速特性長についても、 ガスでは既往の業務用レンジ $(7 \mathrm{~kW})$ の結果とはほほ同等である。ま た、ガスはいずれも上昇途中で縮流になる傾向があること、電気 は本報告以外は上昇するにつれ急激に特性長が大きくなることが わかる。さらにガスは発熱量が大きいほど特性長が大きくなる傾 向があるのに対し、電気はむしろ発熱量の小さい家庭用レンジの 方が特性長が大きい傾向がある。

濃度については既往の研究ではガスが燃焼廃ガス、電気では鍋 内に放出したトレーサーガスを対象に測定しているので、ガスは 本報の $\mathrm{CO}_{2}$ の測定値、電磁は $\mathrm{SF}_{6}$ の測定値と比較した。電気、ガス で特性長に大きな違いはないが、風速と同様にガスが発熱量が大 きいほど特性長が大きいのに対して、電気はむしろ発熱量の小さ い家庭用レンジの方が特性長が大きい傾向があることがわかる。

\section{6. まとめ}

本報では、業務用影房について CFD 解析を行うための基礎デー 夕を得ることを目的として、業務用ガスレンジおよび電磁レンジ について、自由空間内で 1 口のみ使用した時の、上昇気流の温度、 風速、乱流統計量、濃度分布を測定し、レンジ上高さ $0.5 \mathrm{~m} か ら ~ 1.5 \mathrm{~m}$ までのモデル化を行い、既往の測定例との比較を行った。

CFDによる解析を行うには初期条件として以下の情報が必要に なる。

1)器具寸法、形状、発熱量

2)上昇気流の温度分布、風速分布、濃度分布のモデル化した值

3)乱流エネルギーについての情報

4)渦の長さスケールに関する情報

本報告ではこのうち、1)が既知であるガスおよび電磁レンジを

図 23 既往のレンジの上昇気流との特性長の比較（測定值） 
用いて、2),3)について測定とモデル化を行い、以下の点を明らか にした。

・温度、風速、濃度がそれぞれ正規分布で近似可能である。

・発熱量の異なる器具のデー夕を用いて近似することは難しい。 ·風速と乱流エネルギーの平方根との関係は、電磁では比例しそ の比例係数は 0.3 程度であるが、ガスでは温度変動の影響が大き く比例係数の明確な值は不明である。

また4)の渦の長さスケールについては今回の測定では顕著な傾向 がみられず、今後のCFDによる検討を行う際の課題である。これ らの結果をもとにCFDによる業務用欴房の環境評価を行う予定で ある。

なお本研究は大阪ガス（株）からの委託研究の一部として行っ たものである。

[謝辞] 本論文作成にあたり、県立新潟女子短期大学講師・坂口 淳氏のご好意により文献8の実験データのご提供を頂きました。こ こに深く謝意を表します。

注

1）上帠父流の垂淔力问以外の成分について確認するため、事前にガスレンジ について、超音波風速㬀を用いて 3 次元風速を測定した。その結果、高さ $1.0 \mathrm{~m}$ にて水平方向の風速は上问き風速の $1 / 10$ 以下（風速 $0.15 \mathrm{~m} / \mathrm{s}$ 以下）で あった。電磁については結露するため測定不可能であったが、可視化によ る限りガスと同様に主流は上向きであると考えられる。

2）相関利用法：主流方问に並べた 1 対の熟線風速計の出力停号の相互相関関 数と、熱式風速壾間の跳離から風速を求める方法。本試験では熟線風速計 は補闵1のように設置している。

3）熟式風速計はレンジ上力のように高温で温度変化が大きい可能性のある所 では風速の測定䛊差を碓認する必要がある。今回、主流方问のはっきりし ている上昇父流の中心付近について、温度の影響を受けない風速測定方法 である相巨相関関数利用法と中温度用アネモマスターと湘定結果を比較し

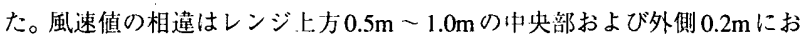
いてほほ㨁線の相関があり、2つの測定結果の差は平均 $10 \%$ であった。

4）温度変化の大きな場で、十分な芯答性を確保して温度変動の影響を測定し た既往の研究例としては、義汇ら (3)が、高温鉛直加熟壁近傍の自然対流に ついて、直烽 $0.012 \mathrm{~mm}$ の熱電対を用いて実験した報告があげられる。義汀.

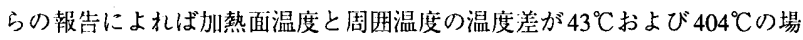
合、いずれも温度の分散の平方根は、加熱面温度と周明温度の温度差に対 し最大で $15 \%$ 前後である。仮に、今回の測定においても、温度の分散の平 方根が上帠気流の最高温度と周囲温度との温度差の $15 \%$ 程度と仮定した場 合、それらが乱流エネルギーの測定值に与える誤差はガスで最大 $0.17 \mathrm{~m} / \mathrm{s}$ 、 電磁で $0.07 \mathrm{~m} / \mathrm{s}$ 程度と見皘もら机る。

5） 4 章・汶 13 で行ったモデル化で、温度について 2 次元の正规分布を仮定し、 測定した 2 䌷上からずれた位置にある最大俌を推定している。この推定値

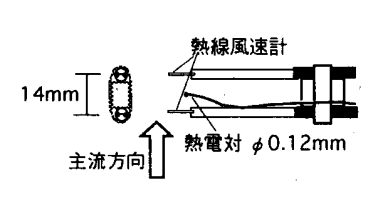

補図 1 相関利用法での 風速測定方法

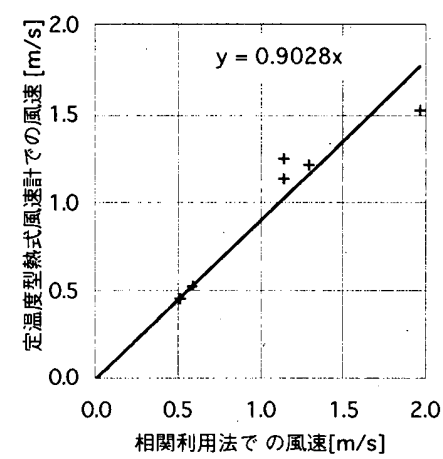

補図 2 定温度型熱式風速計と相関利用法の 風速測定結果の比較 (ガス・高さ $1 \mathrm{~m}$ )
と害際の最大值の誤差について検討するため、ガスレンジの上方高さ $1.0 \mathrm{~m}$ において、XY軸での測定と间時に、別途トラバーサーで最高温度を探し ながら測定した。その結果、上昇気流の中心位置が XY 軸より $0.05 \sim 0.1 \mathrm{~m}$ ずれている場合、本モデル化によって求められる最高温度は、実測で求め た最高温度より平均 $3 \sim 4^{\circ} \mathrm{C}$ 低く見積もる傾向があることがわかった。これ はこの高さでの周囲との温度差の6〜7\%に相当する。

\section{本研究に関連する口頭発表}

1) 山本晃裕, 山中俊夫, 甲谷寿史, 百瀨敏成：業務用ガス・IHレンジから の上昇気流性状の把握, 空気調和 - 衛生工学会近畿支部学術研究発表会 論文集, pp.107-110, 2002.3

2) 山本晃裕, 山中俊夫, 甲谷寿史, 百瀨敏成 : 業務用ガス・IHレンジからの熱 上昇気流性状のモデル化, 日本建筑学会近畿支部研究報告集, 第42号, pp 365$368,2002.6$

3) 山本晃裕, 山中俊夫, 甲谷寿史, 百瀨钽成：業務用欴房における天井換気シ ステムの設計法に関する研究，(その2) レンジの熱上昇気流モデルから作 成した境界条件を入力とする CFD 解析, 日本建築学会大会学術講演梗概集 D2, pp.819-820, 2002.8

4) 百瀨敏成，山中俊夫，甲谷寿史：業務用ガス・IHレンジからの上梨気流性 状の把握，（その2）乱流統計量の測定に基の゙く上昇気流の CFD 解析,平成 14 年度 空気調和 ·衛生丁学会学術講演会講演論文集 D-31, pp793-796, 2002.9

\section{参考文献}

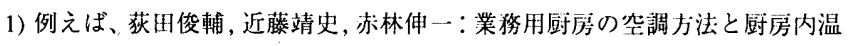
度に関するCFDによる検討, 日本建築学会大会学術溝演梗既集, pp. 973-9.74, 1998. 9

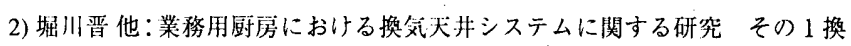
気天井システムの概要と数伯シミュレーション,日本建築学会大会学術講演 㭺溉集, pp.1057-1058, 2001.9

3）于穎、楢崎正也、佐藤隆二、川中俊夫：ガスレンジによる調理時の熟上䒜 気流のモデル化，住宅嶎屏に扔けるレンジフードの捕集效率の予測法に関。 する研究 1 , 日本建築学会計画系論文集 第 434 号, 1992.4

4) Chen, C.J. and Rodi, W. :Vertical Turbulent Buyant Jet-A Review of Experimental Data-, Pergamon Press, 1980

5) 鎌田元康：住宅に㧍忛る局所换気装置に関寸る研究，住宅総合研究財団 , 1993

6) 千葉䰻,小峯裕已, 倉渕隆,鎌田元康、八乙女嶡、高草智：家庭用電化屍 房の局所換気方式に関する研究 (その2), 同時給排気型レンジフードに関 する実験的研究, 平成 6 年度 空気调和・衛生工学会学術講演会講演論文集 C-15, pp.193-196, 1994.10

7) 寺沢正浩, 赤林伸一-, 近藤靖史, 坂口淳, 上村直純：業務用厚房の高効率 換気・空調システムに関する研究 その 2 レンジ上の温度分有及び風 速分布の測定結果, 日本建築学会学術講演梗溉集 D, pp.727-728, 1994.9

8) 坂口淳, 赤林伸一, 近藤靖史, 川瀬貴晴, 荻田㑆輔：実大実験による換気・ 空調効率の測定 業務用於房の高効率換気・空調システムに関する研究 その 1 , 日本建築学会計画系論文集 第 534 号,pp.33-40, 2000.8

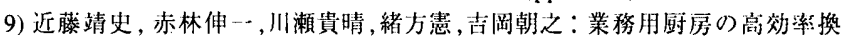
気・空調システムに関する研究 その 4 刘流・放射連成解析による父流・ 温度分布および換気効衡の検討, 平成 6 年度 空気調和・衛生工学会学術講 演会講演論文集 C-17, pp201-204, 1994.10

10) 寺井俊夫, 新旧勝通：燃焼面熟源より上昇するPLUMEについて, 日本建 筑学会大会学術講演梗概策, pp.189-190, 1976. 10

11) 寺井俊夫, 新田勝通 : 燃焼面熱源より上屍するPLUMEについて（その2） , 日本建筑学会大会学術講演梗概集, pp.257-258, 1978.9

12) Peter Kofoed," Thermal Plumes in Ventilated RoOMS" ,Ph.D.Thesis,Aalborg University,pp.57-59, 1991. 1

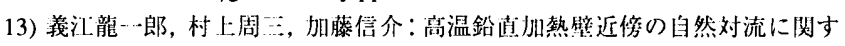
る実験,密度変化を伴う高浮力流机の数值シミュレーションに関する研究 第 2 報, 日本建筑学会計画系論文集,pp.61-68, 1994.7

(2002年 9 月 10 日原稿受理, 2003 年 2 月 28 日採用決定) 